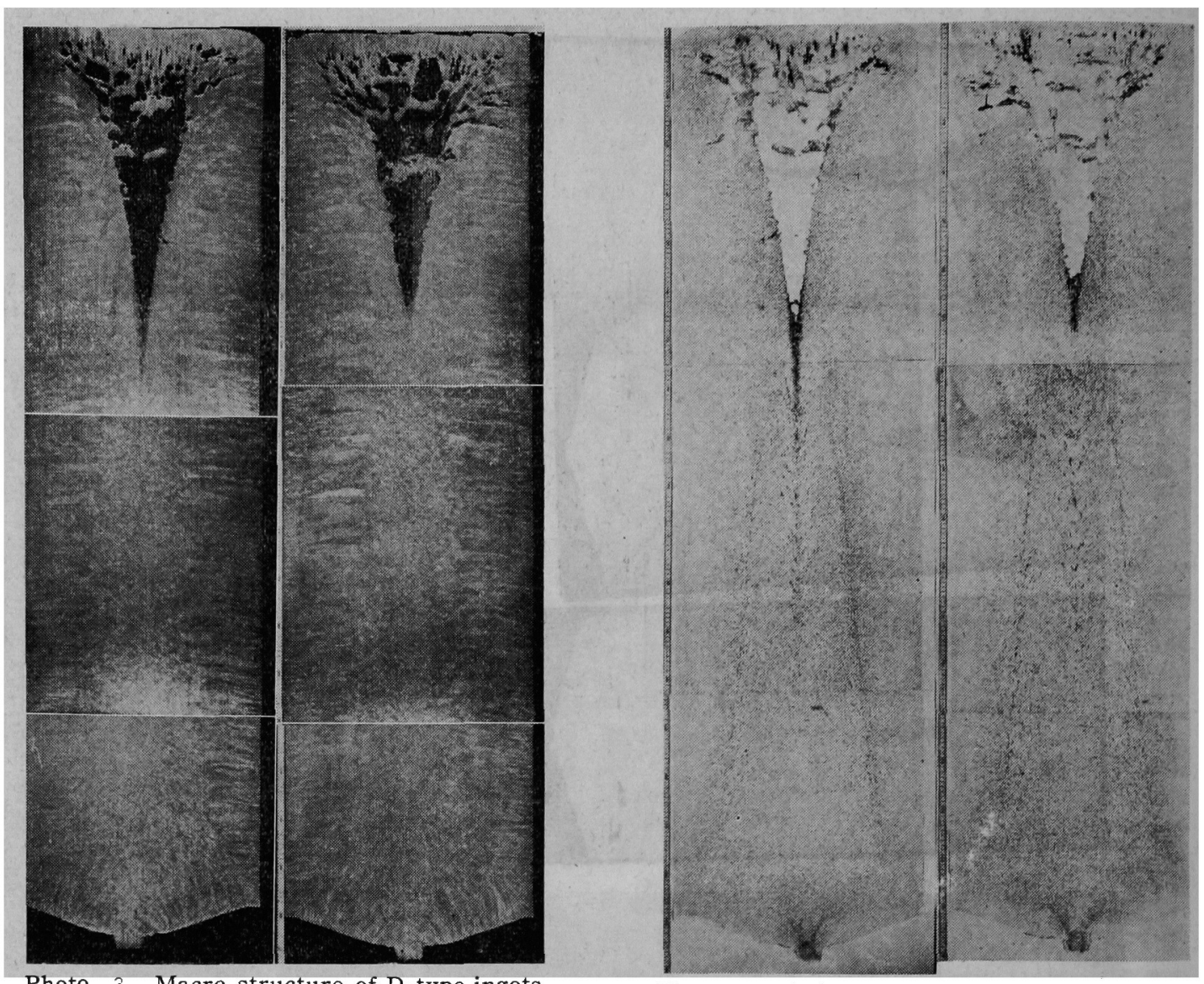

Photo. 3. Macro structure of D-type ingots.

Photo. 4. Sulphur print of D-type ingots.

Table 4. Apparent specific gravity of ingot and height of cavity.

\begin{tabular}{c|c|c|c}
\hline \hline $\begin{array}{c}\text { Ingot } \\
\text { type }\end{array}$ & $\mathrm{H} / \mathrm{D}$ & $\begin{array}{c}\text { Apparent } \\
\text { specific gravity }\end{array}$ & $\begin{array}{c}\text { Height of } \\
\text { cavity }\end{array}$ \\
\hline $\mathrm{D}$ & $3 \cdot 71$ & $\begin{array}{c}7 \cdot 75 \\
(6 \cdot 64)^{*}\end{array}$ & $32 \%$ \\
$\mathrm{C}$ & $3 \cdot 5$ & & \\
\hline
\end{tabular}

（124）均熱炉におけるセミキルド鋼塊 の倒立装入について

八幡製鉄所，技術管理部

$\begin{array}{lrr}\text { 甲斐 } & \begin{array}{r}\text { 幹・市川 } \\ \text { 技術研究所 }\end{array} & \text { 保・高木清八郎 } \\ \text { " 神田 光雄 } \\ \text { 技術管理部 } & \text { ○元田 欽也 }\end{array}$

る透よ視などが広く使われているが，銓塊の見か け比重の測定によつて，ほぼ央態を推測できなこ とが判明した。

2）鋼塊の H/D が大きくなるにしたがい, 銅塊上 部の㠜固速度が早くな念ため, 後注ぎによる「押 し」の効果が大となり収縮孔の割合は小さくな $\vec{b}$.

3）鋼塊上部の凝固速度を早くするような注入法をと ることによつて，2）と同様な結果となり，収縮 孔は減少する。

4）収縮孔を鋼塊上部に集中するためには，押湯付鋼 塊と同様に，下部からの冷却を強化することが必 要であろう.
On the Upside Down Charging for Semi-Killed Ingots in Soaking Pits. Tsuyoshi KaI, Tamotsu IchIKAwa Seihachirõ TAKAGI, mitsuo KANDA and Kinya Motoda

\section{1. 緒咅}

セミキルド銅塊に存在する内部欠宿は, 圧延後も残留 し鋼片または製品に出現することがあるので,ての出現 を防止することが製造上の大きな問題の一つである.

この防止対策の一つとして当所では均熱炉に打いて鋼塊 の倒立装入を実施しているので，てれに関する技術的諸 問題について報告する. 


\section{2.工場 試 験}

セミキルド鋼塊について鋼片パイプ，または製品パイ プ発生を減少させるために鋼塊の倒立装入試験を各錋 種について数回にわたつて央施したので，てれらの試䍄 要領および試験結果の概要を説明する。

$2 \cdot 1$ 均熱炬に打ける鋼塊装入方法

$2 \cdot 1 \cdot 1$ 正立装入

鋼塊を造塊場で型抜きしたままの姿勢で均熱炉に装入 するのが正立装入であり，当所の通常作業がこれであ る.

$2 \cdot 1 \cdot 2$ 倒立装入

鋼塊を造塊場で型抜きしてから，製銅工場または分塊 工場で鎆塊装入機によつて転倒し, 型抜時とは天地を逆 にした姿势で均熱炉に装入するのが倒立装入である。

$2 \cdot 2$ 試 験 要 領

1）試験鋁種セミキルド条鋼材，七ミキルド厚板 材

2) 試験単位チャージを2分割しておの招のを正 立，倒立装入する

3）倒立を行なう工場 分塊または製鋼工場

4) 均熱哣形式 特詣定しない

5）調查項目 i ) 鋼塊頭部形状

ii）鋼片别よび製品パイプ発生状況 iii）均熱炣内に打ける鋼塊表面温度

iv）鎆塊または鋼片切断調查

当所では製銓 $\rightarrow$ 分塊 $\rightarrow$ 製品压延という工程により製品 は製造されているので，鋼塊のパイプは中間製品である 鎆片（スラブまたはブルーム）と最終製品に出現する. したがつて鎆片と製品の両者を試験の対象とした。

\section{$2 \cdot 3$ 試験 結 果}

$2 \cdot 3 \cdot 1$ 製品パイプ

製品パイプについて峦入法別に娭定した結果をTable 1 亿示す.

Table 1 から倒立装入が製品パイプの減少に効果の あることがわかる.またセミキルド厚板材について装入 法別に超音波探賃を行なつた例があるが，倒立材の欠陥 発生率は正立材よりも品種Dで $1 \cdot 0 \%$, 品種 Eでは $1 \cdot 8$ \%少なかつたこ.（の場合の欠陥発生率の表示は次式に よる。

欠陥発生率 $(\%)=$ (欠陷探傷個数)/(総探賃個数) $\times 100$ しかしながらすべての鋼種について探立装入の効果が

Table 1. Comparison of occurred internal defects.

\begin{tabular}{|c|c|c|c|}
\hline 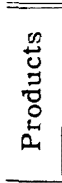 & 蒈 & $\begin{array}{l}\text { Difference of occurred } \\
\text { internal defects }(\%) \\
\text { Difference between } \\
\text { normal charging(I) } \\
\text { and upside down } \\
\text { charging(II) (I) }-(\text { II) }\end{array}$ & Note \\
\hline \multirow{3}{*}{ 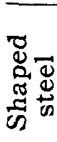 } & A & Co & $\begin{array}{l}\text { Rejected pieces } / \\
\text { Total pieces }) \times 100\end{array}$ \\
\hline & B & $3 \cdot 8$ & \multirow{2}{*}{$\begin{array}{l}\text { (Rejected weight/ } \\
\text { Total weight) } \times 100\end{array}$} \\
\hline & C & $2 \cdot 2$ & \\
\hline \multirow{2}{*}{ 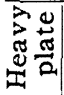 } & D & $5 \cdot 6$ & \multirow{2}{*}{$\begin{array}{l}\text { (Rejected sheets } / \\
\text { Total sheets) } \times 100\end{array}$} \\
\hline & $\mathrm{E}$ & $6 \cdot 2$ & \\
\hline
\end{tabular}

認められたわけでなく，効果が十分には認められないも のもあつた.

\section{$2 \cdot 3 \cdot 2$ 鎆片パイプ}

鋼片パイフについて装入法別に調查した例を示す。

i ) 七ミキルド条鐝材品種 $\mathrm{A}$

分塊でのパイプによるブルーム切捨量が倒立材では正 立材よりも $1 \cdot 0 \%$ 減少した。(この場合の鋼片パイプ発

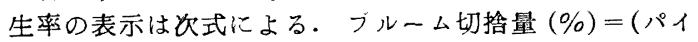
プによる切捨屯数 $) /($ 鋼塊屯数 $) \times 100$ )

ii) 七ミキルト条鋼材 品種 $\mathrm{B}$

鋼片の残留パイプ長さを超音波探第により調查した結 果では，倒立材では正立材よりも平均的に $260 \mathrm{~mm}$ 短か かつた。

このように鎆片パイプについても倒立装入の効果が認

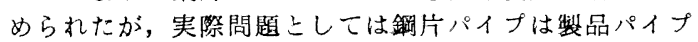
とは異なり，たと䜽片の切捨量が少なくてパイプが残 留してもこれが必らず最終製品に出現するとは限らない のであまり重要視はしなかつた。

$2 \cdot 3 \cdot 3$ 脱酸度打上び装入法

製品パイプについて脱酸度扔よび装入法別に比較した 結果を Fig. 1，Fig. 2 に示す. 眖酸度としてはセミキ ルド鋼塊の頭部形状と取鎝 $[\mathrm{Si}] \%$ を採用した。

Fig. 1, Fig. 2 から脱酸度については，これが過多 になつても不足になつても製品バイプ発生率が増加する ことが示され，また装入法では倒立材の製品パイフ発生 率が少ないことが示される。

\section{$2 \cdot 3 \cdot 4$ 鋼塊の均熱度}

均熱炣の形式によつて炣内の温度分布, 打よび燃焼ガ スの流れに差異があり，これが銅塊の均熱度およびスケ 一ル生成量に重大な影響を与えるといわれているが，当 所の試験結果でも均熱炣内に温度差がある場合，装入法 によつて鋼塊の均熱度に差異があることがわかつたので この結果を次に示守.

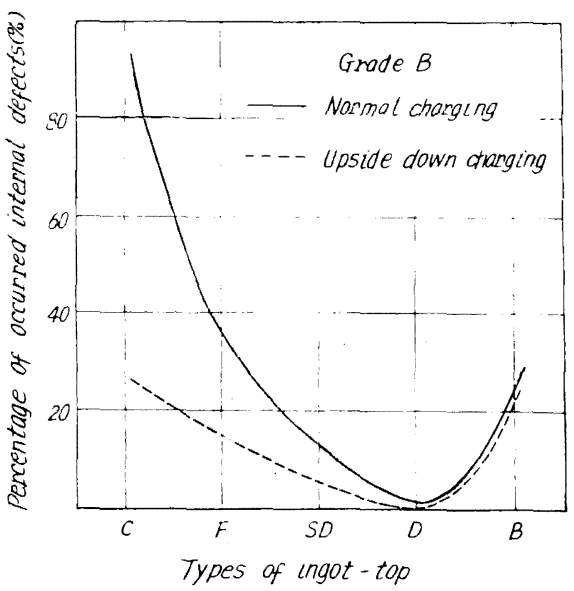

$$
\begin{array}{ll}
\text { Types of ingot-top. } & \\
\text { C : Concave. } & \text { D : Dome. } \\
\text { F : Flat. } & \text { B : Bleed. }
\end{array}
$$
SD : Slightly dome.

Fig. 1. Relation between types of ingot-top and internal defects. 


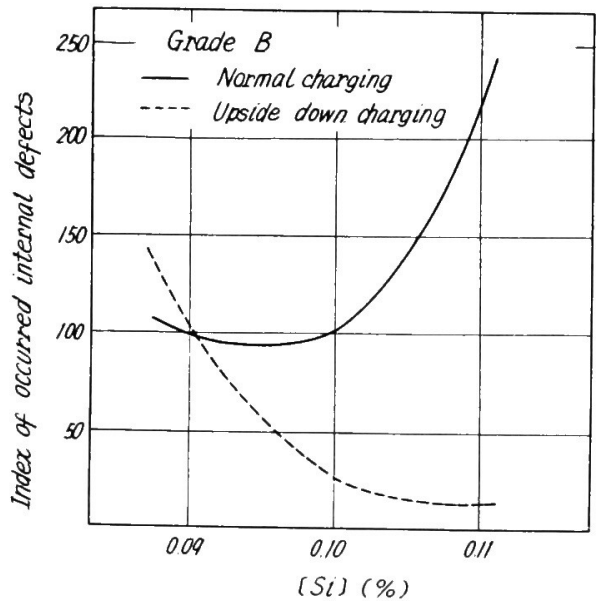

Fig. 2. Relation between [Si] and occurred internal defects.

i ) 焒内天井部側の温度が高い均熱炉

下広鋼塊を正立装入方ると鋼塊頭部（炉内天井部側） が過熱され鋼塊底部（炉床部側）との温度差が大になる が，倒立装入するとこのような温度差が少なくなり均熱 度が向上する

ii ) 炉床部側の温度が高い均熱炉

下広鋼塊を倒立装入方ると鎆塊頭部（炉床部側）が過 熱され鋼塊底部（炉内天井部側）との温度差が大になる が，正立装入するとこのような温度差が少なくなり均熱 度が向上する。

$2 \cdot 3 \cdot 5$ 鋼塊頭部切断調査

鋼塊頭部を切断調查した結果を Photo. 1 亿示す.

\section{3. 実際作業への適用}

工場試験結果から倒立装入の効果が認められた鋼種に

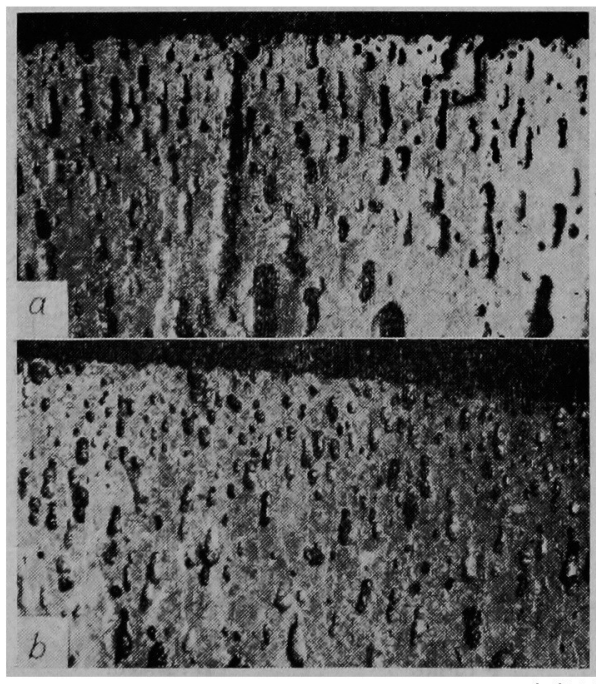

a) Normal charge. b) Upside down charge. Photo. 1. Macrostructure of ingot.

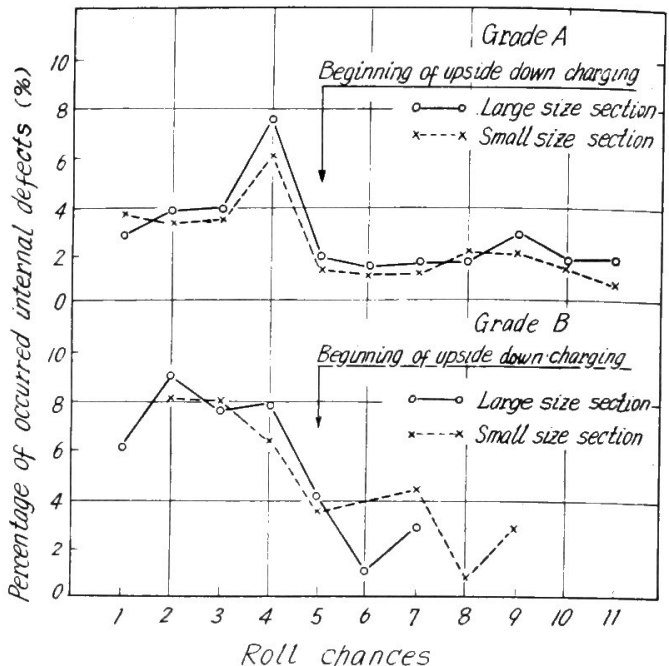

Fig. 3. Changes of occurred internal defects.

ついては倒立装入を実際作業として行なうことにした。 この結果製品パイプの発生率が減少しだので推移をFig. 3 亿示す.

\section{4. 考察}

$4 \cdot 1$ 倒立䒾入の効果について

倒立装入がパイプに起因した疵の出現防止に効果のあ る理由としては次のようなことがあげられる。

$4 \cdot 1 \cdot 1$ 鋼塊頭部の酸化防止

正立鋼塊上倒立鋼塊を切断した調查結果では次のよう な点が明らかにされた。

i ) 鋼塊天井部気泡

正立鋼塊では鋼塊天井部気泡が外気中に露出されるが 倒立鋼塊ではこの露出程度が少ない。

ii ) 脱 炭 風

正立鋼塊では鋼塊頭皮直下部が，ほとんど全体にわた つて脱炭され，外気に通ずる気泡周辺には無数の $\mathrm{FeO}$ が存在するが，倒立鋼塊ではこの脱炭程度が少ない，

このように倒立装入によつて，鋼塊頭部が均熱炉炉床の コークブリーズの中に没入することによつて，酸化程度 が少なくなるため鋼塊内のパイプおよびパイプ性気泡の 内面酸化が防止され圧着性が向上するものと思われる.

$4 \cdot 1 \cdot 2$ 溶融スケールまたはスカムの流入防止

ミセキルド鋼の頭部スカムの融点は $1300^{\circ} \mathrm{C}$ 前後と考 えられるので, 正立装入の場合にはスカムが鋼塊パイプ 内に流入する可能性がある。またスケールとスカムが共 存すれば融点はさらに低くなり流入しやすくなると思わ れる、したがつて倒立装入を行なえば鋼塊パイプ内面の 污染が防止され，圧着性が向上するものと思われる。

$4 \cdot 2$ 倒立装入実施の条件

$4 \cdot 2 \cdot 1$ 眖 酸 度

セミキルド鋼は品質上の要請から材質を向上させるた めに脱酸度を強くする場合があるが，倒立装入はこのよ うな場合に効果が大きい，また脱酸度が強い鋼種ではな くてもなんらかの理由によつて脱酸度が強くなつた場合 も同様に効果が大い。 


\section{$4 \cdot 2 \cdot 2$ 品種}

品種によつてパイプ発生率の高いものと低いものがあ るが, 倒立装入はパイプ発生率が高い品種に特に効果が 認められる。（パイプ発生率の高い品種は，一般に眖酸 度が強いかまたは鎆塊から製品への錹鍊比が小さいかの どちらかである。

$4 \cdot 2 \cdot 3$ 倒立装入材の適正脱酸度

試験結果から眖酸度が弱い場合に倒立装入を行なつて もパイプは娍少しないので, 倒立材の適正脱酸度は一般 に正立材よりも強くしたはうがいいようである。倒立材 の脱酸度を強くすることは脱酸不足によつて鋼片または 製品に出現する表面疵を減少させるという点からも好ま しいと思われる.

$4 \cdot 2 \cdot 4$ 均熱哣形式

倒立鐏塊の頭部の酸化防止という点からは炉床にコ一 クブリーズを散布しない炉とか, 绉床の温度が天井より 高い炉は好ましくないと思われる。しかしながらてれら の炬でも倒立装入によりスカムまたはスケールのパイプ 内流下防止の点からは効果があると思われる。

$4 \cdot 3$ 倒立䒾入を実施する場合の作業的問題

倒立装入を実施する埸合の最大の問題点はトラックタ イムの延長することである．品質上，倒立装入を行なう 場合の鋼塊の凝固程度は正立装入を行なう場合よりも進 行しているのが望ましいので，トラックタイムが延長す るわけである。この場合の鋼塊倒立は製鋼，分塊のどち らでも可能であるが, トラックタイムを延長させないた めには分塊で行なうのが望ましい.

\section{5. 結啇}

セミキルド鋼塊の内部欠陥が鋼片または製品に出現す るのを防止するため均熱炬に打いて鋼塊の倒立装入を実 施した結果次のような結論が得られた。

1. 工場試験を実施し倒立装入を行なえば鋼片または 製品パイプが減少する鎆種があることがわかつた。

2. 効果のある鋼種について実際作業に倒立装入を適 用した結果，製品パイプ発生は著しく減少した。

3. 倒立装入の効果，倒立装入の実施条件，作業上の 問題点について考察を加えた.

\section{大型鍛造用鋼塊の凝固ならびに 偏析に関する考察}

（丸型鋼塊の金型部の凝固についてーI） 三菱製鎆，長崎製鎆所

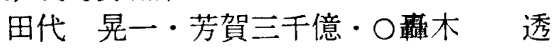

Study on the Solidification and Segregation of Large Steel Ingots for Forging. (On the solidification of chilled parts of round ingots - I)

Kōichi Toshiro, Michio Haga and Töru TODOROKI.

\section{1. 緒言}

鋼塊の偏析を解明するに当つて，乙れと密接に関連す る銅塊の疑固状態を十分に把握することが必要であるて とは論を俟たない，との意味でまず鋼塊を金型部および 押湯部（断熱部）に大別してれらの凝固について調査を 行ないその結果を鋼塊の偏析と関連させて考察して行く
こととした．まず第 1 報としては鋼塊本体すなわち金型 部の凝固に関し考えてみることにする．銓塊の凝固に関 しては今日までかなり多数の研究が発表されているがて れらの研究は主として鋼塊の凝固完了時間を主体に取圾 つて扣り，凝固過程に扔ける凝固殼の生成状況に関して は殆んど触れていない，著者らは大型鋼塊に発生する内 部欠陥特に逆 $\mathrm{V}, \mathrm{V}$ 偏析などの欠陥が凝固先端の凝固速 度と関連があるのではなからうか，との見解よりまず手 始めとして大型鍛造用鉡塊について Bar. Test 法, あ るいは $I . M . \mathrm{MACKENZIE}^{1)}$ が行なつた方法による鋳型 の温度分布の測定, 更に接触型温度計あるいは光高温計 に上る凝固過程中の鈯塊表面温度の測定などの実测を行 なうと共に，河合ら2により考案された凝固式を一部補 正して新たに凝固式を誘導し央測值と結合して横凝固, 維疑固の実験式を求め 2,3 の考察を行なつた。

\section{2. 凝固式の誘芼}

鎙塊の凝固に関してはその形状によりいろいろ異なつ た凝固式が与えられるはずであるが，ここでは鍤造用鋼 塊を主体として考え，底部の定盤のみにより行われる繸 方向の凝固（いわゆる縦频固とは異なる）と，鋳型への 伝熱を主体として行われる横方向の凝固（横凝固）の二 つに分けて考えるてとにする。もちろん，鍛造用鋼塊で あるので横凝固は円筒と考え計算を行なうことにする.

\section{$2 \cdot 1$ 横凝固 式}

今鋼塊形状を半径 $\mathrm{R} の$ 無限円筒として熱の移行は水平 方向のみと考え, 溶鋼の過熱, 過冷を無視した場合は, 任意時間に打ける凝固厚さ $\delta$ を有する凝固中の鋼塊に おいて, 更に $\mathrm{d} \delta$ の厚さが凝固する際は, 凝固熱および $\delta$ 部分の含熱量変化が鋳型を通して外部へ放出されるこ とになる．この状態において凝固㒸 $\mathrm{d} \delta$ の凝固熱を $\mathrm{dQ}_{1}$ とすれば

$$
\mathrm{dQ}_{1}=1 \cdot 07 \gamma_{\mathrm{L}} \cdot 2 \pi(\mathrm{R}-\delta) \cdot \mathrm{A} \cdot 1 \cdot \mathrm{d} \delta \cdots \cdots(1) \text { となる }
$$
ただし $\gamma_{L}$ ：溶鋼の比重, A：凝固の潜熱, 1：円筒の任 意長さ，1.07 $\gamma_{\mathrm{L}}$ ：凝固点における固相の比重 $=\gamma_{\mathrm{S}}, \mathrm{R}$ : 鋼塊の半径.

次に凝固殼 $\delta$ 内に含まれる含熱量も凝固殼の厚みと共 に変化し，その一部は外壁を通して鋳型に放出されると とになるが，この項を計算に入れることは極めて式を難 解にするのでここでは一応無視して計算を進めるてとに する．鋼塊の凝固過程においては凝固速度が極めて早い 表囷部打よび中心部の凝固時を除外すれば熱云導の速度 に比べ凝固殼の厚さ $\delta$ はこれ程急激に変化するもので はないからこの過程では $\delta$ を通じての放熱は定常流に 近いと考えてよからう。一方肉厚管の定常流の伝熱方程 式として次式が知られている.

$$
\mathrm{dQ}=\frac{\mathrm{K} \cdot \Delta \mathrm{T} \cdot 2 \pi \cdot 1}{\mathrm{In} \mathrm{R} / \mathrm{R}-\delta} \mathrm{dt} \cdot \cdots
$$

ただし $\mathrm{dQ} ; \delta$ を通して dt 時間に流れる熱量， $\Delta \mathrm{T}=$ $\mathrm{T}_{1}-\mathrm{T}_{2}, \mathrm{~T}_{1}$; 凝固点, $\mathrm{T}_{2}$; 表面温度 (一定), $\mathrm{k}$; 凝固 㐿の平均熱伝導率また $\mathrm{dQ} は \delta$ があまり厚くない間は 近似的に次式で表わされる

$$
\mathrm{dQ}^{\prime}=\frac{\mathrm{K} \cdot \Delta \mathrm{T} \cdot 2 \pi \cdot 1}{\delta}\left\{\frac{\mathrm{R}+(\mathrm{R}-\delta)}{2}\right\} \mathrm{dt}
$$

したがつて $\mathrm{dQ}^{\prime}=\mathrm{dQ}_{1}$ であるべきなので次式が成立する

$$
\mathrm{dt}=2 \cdot 14 \times \frac{\mathrm{A} \cdot \gamma_{\mathrm{L}}}{\mathrm{K} \cdot \Delta \mathrm{T}} \times \frac{\delta(\mathrm{R}-\delta)}{2 \mathrm{R}-\delta} \mathrm{d} \delta
$$


$2 \cdot 14 \times \mathrm{A} \cdot \gamma_{\mathrm{L}} / \mathrm{K} \cdot J \mathrm{~T}=\alpha$ 上扰き積分すれば $\mathrm{t}=\alpha\left[1 / 2 \cdot \delta^{2}+\mathrm{R} \delta+2 \mathrm{R}^{2} \operatorname{In}(2 \mathrm{R}-\hat{o}) / 2 \mathrm{R}\right] \cdots(1 \mathrm{c})$ したがつて $\delta=\mathrm{R}$ すなわち中心まで凝固化要する時間と $\mathrm{R}$ の関係は

$$
\mathrm{t}=\alpha \times 0 \cdot 12 \mathrm{R}^{2}
$$

で表わされることになる。

\section{$2 \cdot 2$ 底部凝固式の誘導}

横凝圆の場合已同様な条件で，すなわち熱移行は純粋 飞繸方向の及行われ, 過熱, 過冷は無視し任意時間 $\mathrm{t}$ に

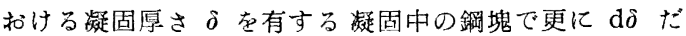
け凝固が進む時，凝固熱抏よで $\delta$ 部分の含熱星変化が 定盤を通して放熱さ机公上考え，単位面積について計算 を行なうと

$\mathrm{K} \cdot J \mathrm{~T} / \delta \cdot \mathrm{dt}=1 \cdot 07 \times \mathrm{d} \delta \times \mathrm{A} \cdot \gamma_{\mathrm{L}}+J \mathrm{~T} / 2 \cdot \gamma_{\mathrm{S}} \cdot \mathrm{C}_{\mathrm{S}} \cdot \mathrm{d} \delta \quad$ か 成立する。こ机を程分なる上

$$
\begin{aligned}
& \mathrm{t}=\left(1 \cdot 07 \times \mathrm{A} \cdot \gamma_{\mathrm{L}}+J \mathrm{~T} / 2 \cdot \gamma_{\mathrm{S}} \cdot \mathrm{C}_{\mathrm{S}}\right) \times \hat{o}^{2} / 2 \mathrm{~K} \cdot \Delta \mathrm{T}
\end{aligned}
$$

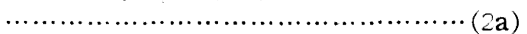

$\left(1 \cdot 07 \times \mathrm{A} \cdot \gamma_{\mathrm{L}}+J \mathrm{~T} / 2 \cdot \gamma_{\mathrm{S}} \cdot \mathrm{C}_{\mathrm{S}}\right) \times 1 / 2 \mathrm{~K} \cdot J \mathrm{~T}=\beta$ とおけば

$$
\mathrm{t}=\beta \hat{o}^{2} \cdots
$$

この式はまた扁平度の大きな扁平鋼塊の㠜固式として利 用できる。

\section{3. 鋼塊の縦凝固速度および衣面温度の測定}

3.1 Bar test 亿よる鋼塊の稼凝固速度の測定

鋼塊の横凝固については前述のように凝固方程式によ

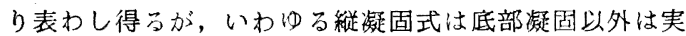
測によらざる在得ない，本実験でも従来行われてきた方 法と扣打上そ同じ方法により，鋼塊の鋳込完了後所定の 時間々隔で鎆塊中心部に $15 \mathrm{~mm} \phi$ の研䄷された Steel Bar を突込み, Bar が中心から外机ないように Guide pipe t使用し $13 \mathrm{~T}, 19 \mathrm{~T}, 35^{\mathrm{T}}$ 釗塊の縦凝固高さを測 定しFig. 1 亿プロットした。緥㠜固には銅塊底部形状 が影響すると考えられるが，19T惼平底であり $13^{\mathrm{T}}$ 下 部直径上同一であるが両者の初期の縦凝固曲線は重なり 合つており，乙の点問題はないものと思われる。いずれ の場合においても縦凝固曲線は,

i ) 初期汇扣いて底部凝固が優先する部分

ii） 中期に扣いて 底部凝固速度が拋物線的に急激に

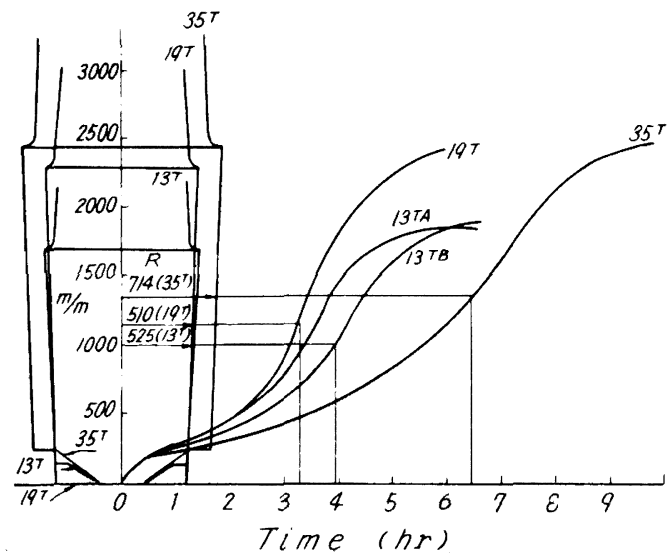

Fig. 1. Vertical solidification curves of several ingots.
減少し横㠜固が優先し鋼塊のテーパーなどの影喓により 直線部老構成方分部分

iii）後期に扣いて押湯の影響により再び凝固速度が 減少する部分.

以上の 3 部に別けられる。いずれの鋼塊も（i）の部 分はかなり近似した曲線を示しこれは定盤による繸方向 の冷却が優先していることを明示している.

$3 \cdot 2$ 凝固中の $35^{\mathrm{T}}$ 鋼塊の表面温度と鋳型の温度分布 の测定

鋼塊の高さ中央付近に打いては下部冷却，拉よび上部 の押湯の影響が少ないので，ての点に扣ける凝固中の銅 塊表面温度を鋳型にセットした測温用プラグにより測温 を行なつた，鋳込終了後鋳型，鋼塊間に空隙ができるた め絶至ずプラグは枕じ込みを行ないその先端は鋼塊に常 に密着せしめた。また鋳型温度分布測定用のプラグは鋳 型と同じ材質の鋳鉄を使用し，プラグと鋳型の接触面に は油練り黑鉛粉末使用しまた鋼塊底部温度も同样にし て測温し 温度分布を調查した（図省略）。ここでプラグ に上る銅塊表面温度の测定は，プラグの熱伝遵による熱 損や，接触による誤差が考えられるので実験的にチェ\% クを行なつた所, プラグによる測温值は真温度に対して 約 $40^{\circ} \mathrm{C}$ 低目に現われることを知つた。 以上の值を補正 して鋼塊表面温度は凝固完了までの約 6 時間は扰打よそ $1000^{\circ} \mathrm{C}$ と固定して考えて大過ないもの上思われ, 前述 の計算で仮定した事項を確認した。

\section{4. 誘迸式と実測值を対比しての考察}

\section{$4 \cdot 1$ 横 凝 固}

Fig. 1 亿示した縦凝固曲線より求められる鎆塊高さ の中央部の凝固時間の平方根に対して半径をプロットし （図省略）この直線の勾配を求めるととにより誘遵式 (1d) の $\alpha$ を求め机ば $\alpha=106$ を得る。よつて (1c) (1d) 式注

$$
\mathrm{t}=106\left[1 / 2 \delta^{2}+\mathrm{R} \delta+2 \mathrm{R}^{2} \operatorname{In}(2 \mathrm{R}-\delta) / 2 \mathrm{R}\right) \cdots(1 \mathrm{c})^{\prime}
$$

中心の凝固完了時間は $\mathrm{t}=12 \cdot 7 \times \mathrm{R}^{2} \cdots \cdots \cdots(1 \mathrm{~d})^{\prime}$ ただし $\mathrm{t}$ は $\mathrm{hr}, \mathrm{R}, \delta$ は $\mathrm{m}$ です. $\mathrm{R}=714 \mathrm{~mm}\left(35^{\mathrm{T}}\right)$ の $\mathrm{t}$ - $\delta$ 曲線立上式により求めると Fig. 2 のごとくなる.

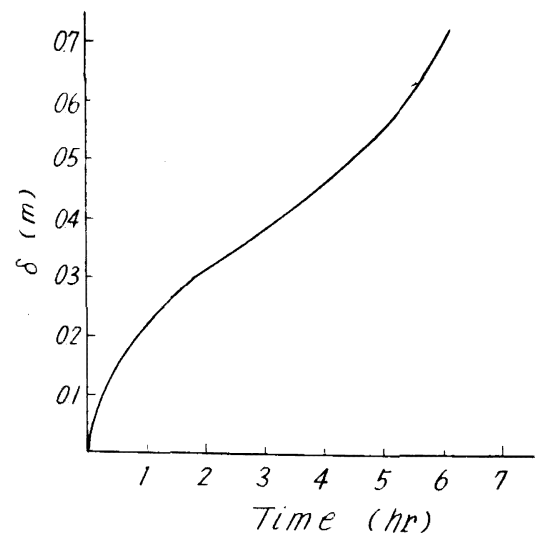

Fig. 2. Relation between the time from the beginning of the solidification and the thickness of the shell of round ingot. 


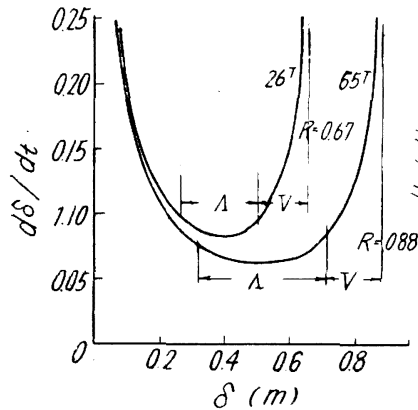

(a)

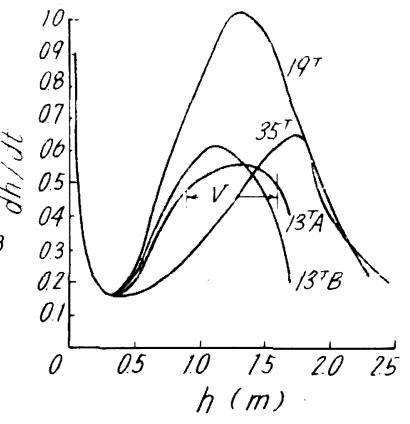

(b)

a) Holizontal solidificatlon.

b) Vertical solidification.

Fig. 3. Rate of solidification.

\section{$4 \cdot 2$ 底部疑固}

先に誘尃した底部凝固式（こb）に関して横凝固の場合 と同様の手法により各銅塊について初期の底部凝固が優 先する部分こ， $\delta と \sqrt{\mathrm{t}}$ に関してプロットし（図省略） これより 1 1.5 hr に如けっ平均勾配として 0.27 を得 る.よつて $\beta=13 \cdot 7$ が得られ求める実験式は

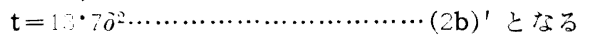

ただし $\mathrm{t}$ は hr，oは $\mathrm{m}$ で示子。また底部よりの冷却は 鋳型の冷却に比心゙てかなり強いが，この泠却も平面の冷 却であるため急激に娍衰する点よりいわゆる底部冷却に は余り大きな期待はできないであうう.

\section{๖. 害験式の検討}

以上の結果の中で底部凝固式に関しては計算上の問題 は殆んど無いと思われるが，横凝固式に関してはかなり の省略並でに仮定を行なつているので, 計算式に既知の 常数を代入した場合大きな矛盾を生ずるか不かを確めた か，何れも常識的な值が得られ，またJ. SCHNICWIND ${ }^{3}$ が計算により求めたもの上概念的によく一致する点より この式はほは罗当な疑固式至わしていると考えられ ๖.

\section{6. 凝固速度と偏析の関係}

以上の結果より銅塊の凝固状沉の大要が把握できたの でこれらの結果に偏析の関係について考えてみたい.

まず横凝固速度は次式により与えられる。 $\mathrm{d} \delta / \mathrm{dt}=(2 \mathrm{R}-\delta) / 106 \times \delta \cdot(\mathrm{R}-\delta)$

鎆塊平均半径 $670 \mathrm{~mm}, 884 \mathrm{~mm}$ について $\delta$ に対する 穔凝固速度を上式より計算しプロットしたものを Fig. 3aに示した。 これには C 含有量約 $0.05 \%$ の鋼塊縌断 面のサルフフーフリントに上り得られた逆 $\mathrm{V}, \mathrm{V}$ 偏析の 位置を併記したが, 逆 V 偏析は凝固速度がかなり低下し たある值に到達すると現われ始力, 凝固が軸心に近づく にしたがい再び凝固速度が増加するにつれて消失し, 今 度はV偏析が現われること示している。また縦凝固力 一ヴより凝固高さ $\mathrm{h}$ 亿対して縦凝固速度 $\mathrm{dh} / \mathrm{dt}$ 名 鋼塊についてプロットし Fig. 3 b そ示した. 特に $13^{\mathrm{T}}$ 鋼塊についてV偏析の位置を併記したが, 綻凝固が後半 増加する位置で，V 偏析が現われることを示している。 上述の事項は今後更に実験范進めて両者の関係を確かめ る必要があるが，両者の間に大きな関係が有することが 想像できる．次報にはこれらのこよを基整にして鋼塊に
生じる偏析の成因について考察を進めて行く予 定である.

\section{7. 結言}

i ）計算に上る誘導式に実測值を適用する ことにより鏯塊高さ中央部の横凝固式として近 似的に下記の式を得た。

$$
\begin{aligned}
& \mathrm{t}=106\left[1 / 2 \hat{\boldsymbol{o}}^{2}+\mathrm{R} \delta+2 \mathrm{R}^{2} \operatorname{In}(2 \mathrm{R}-\hat{\boldsymbol{o}}) / 2 \mathrm{R}\right] \\
& \mathrm{t}=12 \cdot 7 \times \mathrm{R}^{2}
\end{aligned}
$$

ただし本式は鋼塊本体の凝固完了を示すもの ではない、鋼塊本体の凝固完了はテーパー枕よ び押湯の影㗽があり，上式で求めた值よりかな り時間的に長くなるはずで本式は適用できない が, 本体上部表面温度を同様汇測定すれば, 適 用式の誘導が可能になろうがこれらは押湯方法 によりかなり差異を生ずることは論を俟たな い.

ii）凝固速度とサルフォープリントによる鋼塊の偏 析パターンを比較検討して, 横凝固速度がある限界值に 到達すると逆 $\mathrm{V}$ 偏析が現われ始め, 中心部で再び横凝固 速度か上舁し始めてさらに維凝固速度も早くなると V 偏 析が現われてくると考えられる。

iii）鋼塊底部に打方縦凝固式は $\mathrm{t}=13 \cdot 7 \times \delta^{2}$ で表わされる。

\section{交 献}

1) J. Iron \& Steel Inst. (U. K.), Sept (1950) 19

2) 鉄と鎘, 昭 2437 回講演

3) J. Iron \& Steel Inst. (U. K.) July (1963), p. 594

(126)

\section{ストリングゴーストに関する}

\section{2,3 の観察}

北海道大学工学部

工博 萩原䈑・工博○高橋 忠義

Some Considerations on Formation of String Ghost.

Dr. Iwao Hagiwara and Dr. Tadayoshi TAKAHASHI.
1. 緒
言

大型鋼塊に見られる $\Lambda$ 状ゴーストの生成原因について は，てれまでに多くの研究者によつてそれでれの見解が 提出されている. 近年河合氏1によつても詳細に論じら れている。

本斫究は $75 \mathrm{t}$ 鋼塊からゴースト線を含む部分を切り 出し，これ主として Oberhoffer 試萫による窗食に て,ゴーストを中心にデンドライト結晶の発達状洗など を立体的に観察した結果をもとにして，その生成機棈の 一端を推論するとともに，さらにすでに一部発表した

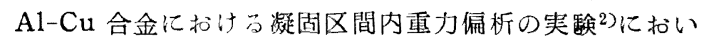
て, 前記の推論を立証ずる現象が見出されたので,ての 結果とあわせて $\Lambda$ 状偏析の生因に関してあらたに一見解 を提示するものである。

\section{2. 実 験 方 法}

$75 \mathrm{t}$ アルミキルド鋼塊（日本㹈鎆所提供）の $2 / 3$ 高 


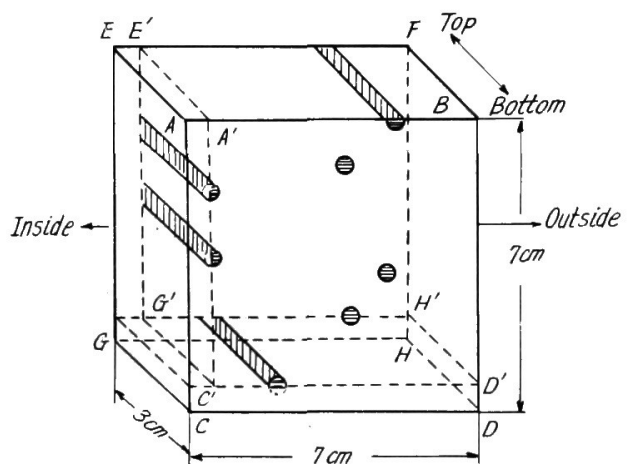

Fig. 1. Schematic diagram of macrostructure (Shaded portion is ghost).
すものである。

ゴーストを中心に立体的に観察した結果を要約すると 次のどとくになる。

1) ゴースト内にあるデンドライト結晶は, 周囲がボ カされているか，あるいは1本のデンドライト結晶が中 途で切られているのが見られる. (Photo. 1-II，II)

2) デンドライト結晶がゴーストを貫通しているもの もある. (Photo. 1-IV)

3）ゴーストによつて，この接触層を除いた左右の結

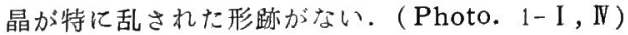

4) 一般にゴーストの外縁が觯明で平滑であるが，内 縁は鋸の歯状になつている。(Photo. 1-II I IV)

5) 外縁の鮮明な部分を細がデンドライト結晶が, 放射状に囲んでいるのが認められる. (Photo. 1- I , II)

6) ゴーストの内側近傍に，かなり大きいデンドラィ 卜結晶がほほ平行に存在している場合もある. (Photo.

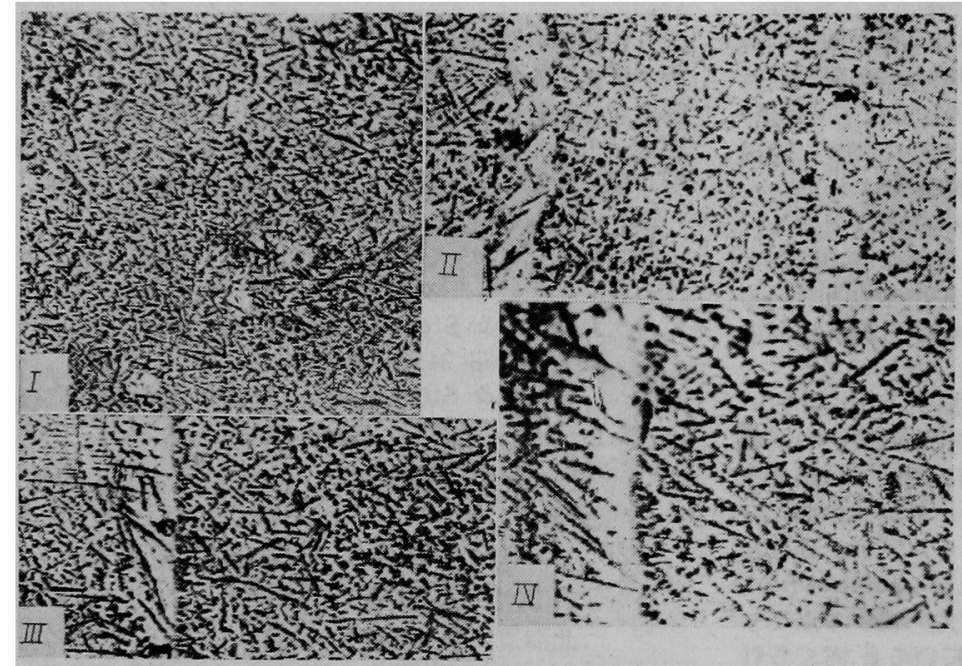

$\begin{array}{ll}\text { I ) } \mathrm{ABCD} \text { section } \times 10^{\circ} & \text { I ) } \mathrm{A}^{\prime} \mathrm{C}^{\prime} \mathrm{G}^{\prime} \mathrm{E}^{\prime} \text { section } \times 1.7\end{array}$

$\begin{array}{ll}\text { II) } \mathrm{C}^{\prime} \mathrm{D}^{\prime} \mathrm{G}^{\prime} \mathrm{H}^{\prime} \text { section } \times 1.5 & \text { IV) } \mathrm{ABEF} \text { section } \times 1.9\end{array}$

$(3 / 5)$

Photo. 1. Macrostrucure ot string ghost: etched with Oberhoffer's reagent.

さに扰けっ肥大晶部分より $15 \times 15 \times 15 \mathrm{~cm}$ のブロック を切り出し, そ机のマクロ写真执よびサルファプリント の結果より，さらにゴースト部分䘮含めた Fig. 1 亿示 すごとく繸，横拈よび厚みが約 $7 \times 7 \times 3 \mathrm{~cm}$ の試料を数 枚採取し，その所要表面たとえば $\mathrm{ABCD}, \mathrm{ABEF}$, $\mathrm{A}^{\prime} \mathrm{C}^{\prime} \mathrm{G}^{\prime} \mathrm{E}^{\prime} ， \mathrm{C}^{\prime} \mathrm{D}^{\prime} \mathrm{G}^{\prime} \mathrm{H}^{\prime}$ などの面に精研磨をはと゚とし， 燐のミク口的偏析を検出するべく, Oberhoffer 試薬に てェッチしたものである。

\section{3. 観察結果と考察}

結果老 Photo. 1- I (A B C D 面), Photo. 1-I ( $A^{\prime} C^{\prime} G^{\prime} E^{\prime}$ 面), Photo. 1- II ( $C^{\prime} D^{\prime} G^{\prime} H^{\prime}$ 面), Photo. 1-N (ABEF面) 亿示す．Ｉは直立するゴースト線の横 断面であり，II鋼塊の半径方向にほぼ直角にゴース卜 2本を縦断した面を示すものであり，ゴーストの左右は 同じ凝固面に掞加れている。 III，N は鋼塊の半径方向に 平行にゴースト各1本を繸断した面を示し，すなわちゴ 一ス卜風塊の内側と外側の両面に接している状況を示

\section{$1-$ III)}

7) 半径方向に直角にまじわる両 面からの観察結果より，ゴースト内 デンドライト結晶は板状であること が，明らかとなつた。 (Photo. 1II)

以上の観察結果上 $\mathrm{Al}-\mathrm{Cu}$ 合金の 凝固区間内凝固に扣け方重力偏析に 関する研究結果とあわせて，ゴース トの生成機構についての 2,3 の見 解を示す.

第一に,ゴーストは凝固進行過程 のいかなる状況のもとで生成するも のであるかということである.この 点については従来多くの説があり， もつこも意見のわかれるところであ る.本钼察結果よりこ扎付対するわ れわれの見解をの心゙る.

一般に柱状晶を経て樹枝状晶の範 囲に入る上，かなり巾のある凝固区 間を有する凝固形態注なり，樹枝状 晶のかなり自由な発達が行なわれ て，その間しだいに外側より内側へこの凝固区間を移動 させつつ凝固を進めていくものである.かかる認識のも とで, その凝固区間内の偏析成分の溲縮程度は, 固相率 の多い外側に向つて大であると考えられる．そのため， 凝固点は低く，温度の勾配がゆるやかであれば必然的に 比重差による流動が可能になり，それがデンドライトの 網目を妨つて抵抗のすくないととろを比較的容易に上昇 して，通路の途中にあるデンドライトの一部を再溶解し つつ，上下につながるトンネルを作り，ての間，集合し やすいものは合体して，ての量を増していくものである と考元られる.また，あるものは局部的流動後さ元ぎら れてとりのこされるものもある。

上記の考元方の基本になつている観察結果をもとにし て, 第一の論点である㠜固区間内に扰いて生成発達する デンドライト結晶網目の中にゴーストの形成する現象に ついて,さらに検討する。

その場合の観察結果の主体は，(1) ( 2 ）（3）䐜であ 
る.すなわち，ゴースト内には比較的るとく数の少ない デンドライトが残されて捛り，それはゴースト外にある デンドライトと異なつてボカされているものが多いてと と，はじめ一簓の連続したデンドライト結晶と思われる ものが途中で切れていること，てれらの事実は主として 灌縮液がデンドライト結晶の網目を上昇する中にこれを 再溶解する現象を示すものと考えられる。また，ゴース 卜によつてその接解風を除いた周囲の結晶が, 特にその 方向を乱された形跡がはととは，ゴーストが形成され る前にすでにデンドライト結晶が生成していたてとを示 すものと考えられる．さらに時にはゴーストを貫通して いるデンドライト結晶が見られることは，いつそうこの 考えを有力にしている。はなはだしく濃度が高く，した がつて凝固点が低いために過冷を失つているゴースト部 分へ, 三の周囲からデンドライト結晶が発逢していく訳 がないからである。

一面これらの観察事実と推論から，ゴーストを含む樹 枝状晶領域こあつても, 熱的要素による結晶の発達分布 亿本質的な影響をあたえることがな，凝固は進行する ものであると理解される。

次に第二の問題として 観察結果（4)（5）項に関す る点についてのべる.すなわちゴーストの外側に面して いる縁が鮮明であつて, 内側に接する部分は鋸の歯状に なつている事実であるが，乙れには凝固区間内デンドラ イト結晶間に生成した富化溶鋼が上昇するときの傾向と して, 粘性抵抗が小さくデンドライト間隙の粗である溉 に向つていくぶん移動していくことが考えられる.した がつて漂縮液の富化程度が上昇中に接するデンドライト 結晶と常に同じ平衝にある領域を通過するものでなく， 換言すれば等凝固面に平行方向に上昇するのではなく， 重力の方向よりも内側斜め上方にむいて上昇する。（従 来の通説では $\Lambda$ 状偏析の傾斜は濃縮液相の上昇速度と凝 固の進行速度の合成の方向とされていた）その結果, 温 度・濃度からくるあらたな平衝関係をつくりだそうとす るために多くのデンドライト結晶の再溶解が行なわれる ものであると考元られる．その際その上昇する富化溶鎆 を中心に見ると，外側江近いものは整縮程度が大で再溶 解する能力が大きく, 一方内側のものは拡散の容易な内

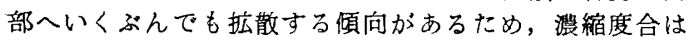
堿少して再溶解能力は外側上り小さいと思われる。した がつて, コーストの外㑡の面は凝固区間の移動とともに 凝固を完成していくわけであるが，その凝固の進行とと もに凝固区間内にある間海等凝固面付近でいくふん不規 則な形状のものが表面エネルギーの小さい円筒状任整え られるものと思われる. これは外側の鮮明な縁の側に微 紐なデンドライトが放射状に囲んで発生している事実か らも推論される.すなわち未凝固部分として残留したゴ 一スト付近の温度勾配がしだいに低下するとともに，コ 一ストの外側限界線を決めっ微結晶がゴースト線沉沿つ てあらたに晶出したものと考えられる. 一方内側につい ては前述したでとく拡散しやすいため一部はうすめられ るととになり, 再溶解能力は弱められ, 既存の比較的大 きいデンドライトはそのままとり残されるとともに，(6) (7)項でのべた事実とあわせて付近のデンドライトの存 在状態により，拡散限界ち決まり，ある程度不規則な形
態をすものと推論される．

次に凝固区間内に存在するデンドライト結晶の網目の

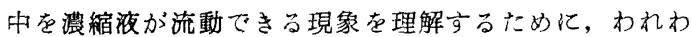
れが $\mathrm{Al}-\mathrm{Cu}$ 合金について行なつた凝固区間内凝固に揖 ける重力偏析に関する実験結果2)を引用する。それは鋳 塊の内外にわずかの温勾配を保ちつつ凝固区間内凝固の 進行する過程でのデンドライト間隙に生ずる浸縮液の重 力偏析現象を追求したものである.実験は内径 $50 \mathrm{~mm}$, 高さ $180 \mathrm{~mm}$ の円筒状の黑鉛情型を用い，溶湯高さは $120 \mathrm{~mm}$ のものである.実臨方法として $\mathrm{Al}-\mathrm{Cu}(4 \%)$ 合金を溶解配合して, 一度 $700^{\circ} \mathrm{C}$ まで上昇させ, しか る後 $650^{\circ} \mathrm{C}$ に下げて（液相線 $648^{\circ} \mathrm{C}$ ), そのまま 30 min 保持後十分復拌してただちに $635^{\circ} \mathrm{C}$ (固相線までい ろいろの冷却速度で冷却し, その後, 直ちに急冷した。 この実嗝に打いてもつとも顕著な重力偏析現象を示した 凝固過程での鋳塊内外の温度差は平均 $1 \cdot 5^{\circ} \mathrm{C}$ であり, その経過時間は $39 \mathrm{~min}$ である.したがつて, その時間 内は鋳塊内外ともに凝固区間内に括かれていたもので温 度測定のみでなく, 実際に pasty 状態を確認した。そ の結果, 凝固区間を徐冷するほど顕著な重力偏析が鋳塊 下部の中央部付近飞示され, 平均銅潾度 $4 \%$ ものが最 大 $7 \cdot 5 \%$ 濃化している結果が得られた。加固相之 液相の割合が相半ばする程度に拈いて, もつとも重力偏 析速度が大であることが見出されている.すなわちかな りデンドライト結晶が発達している時期と見るてとがで きる.したがつてその比較的密なデンドライトの網目を 容易に銅成分が流動していることが考えられるわけであ る. また最大偏析部が鋳塊下部の中央方向に現われるの は, 外部と内部に温度差がある以上凝固は外側よりしだ いに内部に向つて凝固割合が増加するため粘性抵抗が小 さく，障碍の少ない中央，下部に容易になるものと推定 される.

以上 $\mathrm{Al}-\mathrm{Cu}$ 合金に関する偏析現象は本研究の主題で ある鎆塊凝固に初ける炭素・燐・硫黄などの偏析傾向之 はその方向が全く反対ではあるが, 最も重要なととはデ ンドライト結晶の十分発達するような凝固形態，すなわ ち凝固区間を有する凝固では凝固割合のある段階で，デ ンドライト間の覙間に濃化された偏析元素がかなり密に 張りめぐらされたデンドライト結晶の網目の中を容易に 流動して重力偏析現象が行なかれることであり，ての事 実は鋼塊凝固汇扣いても十分考えれれるものであつて， ゴーストの成因について有力な決め手になるものと考え られる。

次に一度生成したデンドライト結晶が濃縮液によつて 再溶解する現象についても, 前記の Al- $\mathrm{Cu}(4 \%)$ 合金 の実験に抲いて示されている.すなわち坩堝の中央に磁 製の冷却パイプを貫通して, 冷風を送入し冷却パイプと 坩堝壁の環状部に冷却パイナに平行に凝固区間域々完全 液相とが半々になるように温度調節によつて平衡させて 保持して行なつた実験結果によれば，平衡状態後直ちに 急冷した場合は凝固区間域上完全液相ごあつた部分は泠 却パイプに平行に上下に同じ厚みであることがマクロ組 織汇認められた。また凝固区間域の上下にははとんど虛 析がなととが分析結果に示された。しかるに平衡状態 をある程度保持すると, 冷風が下部から送られているに 
もかかわらず凝固区間域の巾が下部で滅少するこ上が保 持時間とともに顕著になるここが，マク口写真にはつき り示された。一方分析結果によつても凝固区閵域として 存在した部分には著しい重力偏析傾向が示されるととも に，完全液相であつた部分への拡散も認められている。 これは重力偏析が生しない初期の平衡状態のときに保た れていた凝固区間域と液相との温度と漕度の平衡が，下 部への銅の灌化々ともに凝固点が降下し, 周囲を再溶解 して凝固区間域と液相とのあらたな平衡境界が生じたも のと考えられる。したがつて溳縮液の流動によつてデン ドライト結晶の再溶解現象があり得ることを示したもの と見ることができる。この現象からも鋼塊に掞けるゴー ストの生成にともなう既存のデンドライト結晶の一部が 再溶解され得るものであることが推定できるものであ る。

\section{4. 結 言}

鎆塊に存在するゴーストの生成機権を明らかにするた めに, Oberhoffer 試薬にてゴーストを含む鋼塊の一部 を立体的に観察するとともに， $\mathrm{A} 1-\mathrm{Cu}$ 合金の疑固区間 内重力偏析現象の実験結果と合せて, 次のことが理解さ れた。

1）ストリングゴーストの形成は凝固区間内のデンド ライト結晶のある程度に発達した段階の中で行なわれる とと.

2）デンドライト網目間嶩凝液相の重力による上昇流 動によつて，デンドライト結晶を再溶解して上昇し，そ の結果紐状に滑らかな界面を有するストリングとなつた と見ら机る事実が琶められたこと。

3）裖縮液相がデンドライトの網目の抵抗の少ない方 向に上昇するため，鋼塊の内側方向に傾くものであると 考えられること。

\section{交献}

1) 河合：鉄と鋼, 42 (1956), p.14.

2）高橋，荻原：日本金属学会請演，（1964） 10, p. 109.

(127)

\section{鋼塊偏析におよぼす溶鋼の加圧 の影響}

日本製鋼所，室蘭製作所

○鹿野 昭一・理博中川 義隆

The Effect of High Pressure on the Molten Steel Concerning Segregation of the Steel Ingot.

Shoichi Shikano and Dr. Yoshitaka Nakagawa.

$$
\text { 1. 緒 }
$$$$
\text { 需 }
$$

鋳型内の溶鋼に圧力を加えながら凝固させる方法の実 際的な企ては案外古い歴史を持つている。その最初のも のは WhITWORTH 法 (1889年)1)であり，次いで 1902年 には HARMET 法2)が発表されている.いずれもかなり 大規模な鋼塊に実施されたのであるが，最近り連におい て小型の複永な形状を持つた金型鋳物の鋳造に対して行 なわれている3)4)。乙れら，従来の圧力凝固法は湯引や 収縮管および気泡の発生を防止するのが主な目的であ
ろ.鋼塊においては収縮管や気泡の防止は押湯の節約と 欠陥の防止としては勿論必要なことに属するが，凝居に 対する圧力の影響はそれ以外に著者らの理論的考察によ れば，鋼塊の滆析防止に効果があることが推論されれた。 よつて新たな観点から長い間中断されていた大型鉡塊の 加圧凝固法を再検討した結果，偏析のない均質䤡塊の製 造が可能であること应確認することができた。

\section{2. 加圧凝固法による鋼塊の偏析防止 の理論的根挝 (5)-16)}

$2 \cdot 1$ 溶鋼の性質に対する王力の影響

溶鎆に圧力を加光ることによつて次の諸現象が推論さ れる。

i）比容積の減少

ii ) 凝固点の上昇

溶鋼の比容暴を $\mathrm{V}_{1}$, 凝固後の比容量を Vs, 相変化 の際の吸收らる潜熱志上と字ると，

Clapeyron Clausius の式から

$$
\frac{\mathrm{dT}}{\mathrm{dp}}=\frac{\mathrm{T}\left(\mathrm{Vs}-\mathrm{V}_{1}\right)}{\mathrm{L}}
$$

$\mathrm{T}>\mathrm{O}$, 鋼の場合は $\mathrm{Vs}-\mathrm{V}_{1}<\mathrm{O}, \mathrm{L}<\mathrm{O}$,

結局 $\mathrm{dT} / \mathrm{dp}>\mathrm{O}$

すな方凝固点（T) は圧力（P）の上昇に伴い上昇す る.

$$
\text { 今 } \begin{aligned}
\mathrm{T} & =1805^{\circ} \mathrm{K}(1 \text { 匃圧に扎いて }) \\
\mathrm{Vs} & \left.=7 \cdot 703 \mathrm{cc} / \mathrm{mol}^{15}\right) \\
\mathrm{V}_{\mathrm{l}} & \left.=7 \cdot 9603 \mathrm{cc} / \mathrm{mol}^{15}\right) \\
\mathrm{L} & \left.=3,700 \mathrm{cal} / \mathrm{mol}^{16}\right) \text { とすると }
\end{aligned}
$$

\begin{tabular}{l|c|c|r|r|r}
\hline \hline $\mathrm{P}($ 気圧 $)$ & 0 & 100 & 500 & 1000 & 2000 \\
\hline $\mathrm{T}\left({ }^{\circ} \mathrm{K}\right)$ & 1805 & $\begin{array}{r}1805 \cdot 8 \\
0.8\end{array}$ & $\begin{array}{r}1808 \cdot 6 \\
3 \cdot 6\end{array}$ & $\begin{array}{r}1812 \cdot 1 \\
7 \cdot 1\end{array}$ & $\begin{array}{c}1819 \cdot 2 \\
14 \cdot 2\end{array}$ \\
\hline $\mathrm{T}\left({ }^{\circ} \mathrm{C}\right)$ & & & \\
\hline
\end{tabular}

iii）ガス類の溶解度の增加

iv) 粘度係数の增加と拡散係数の減少

v ) 熱云導係数の增加

$2 \cdot 2$ 銅塊偏析と王力の関係

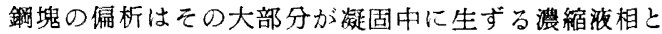
Dendrite skelton の重力による浮上または沈沷に起因 するものであると見てよいから，鋼塊の偏析防止は重力 偏析を防止することであると見てよい.

鋳込後の鋼塊の熱的挙動を述べると，溶鋼の過熱は極 めて速やかにすなわち鋳型の表面に最初の skin が生成 される間の短時間内に失なわれて Liquidus temp. に まで降下するものである。しかし鋼塊の未凝固溶湯がー 定に保たれている温度は真の平衡温度よりも過冷されて いる状惎にあるこ考えられる(これについては別報す る)，乙れが固液相界面の Liquidus からデンドライト 凝固の進行に必要な過冷度ごある。このような過冷を $\Delta \mathrm{T}_{1}$ とすると液相に圧力を加えると Liquidus は $\Delta \mathrm{T}_{2}$ 上昇し, 過冷度 $\Delta \mathrm{T}=\Delta \mathrm{T}_{1}+J \mathrm{~T}_{2}$ となる. 固液相界域の の Liquidus 過冷度はデンドライトの凝固進行に必要 な過冷に既に達しているのであるから, わずかの $\Delta \mathrm{T}_{2}$ の増加でも Aendrite の急激な進行を生し， $\Delta \mathrm{T}_{2}$ の大な るほどすなわち圧力の大なるほど界面よりの dendrite の成長は急速になる。ささに圧力を加えるととによつて 
溶鎆凝固殻と鋳型との間の air gap ができないので鋳 型による冷却効果が増大する。このため凝固は内部まで 急速に継続する。

したがつて，凝固中に扣けっ偏析の時間的余裕を妨げ る.すなわち，デンドライトの存在によつて惯縮液相の 上昇を阻止するため重力偏析は殆ど完全に失なわれるこ とが可能になる.

以上の他に（iv）の効果がこの傾向を助長し，また (iii) と（iv）の効果は非金属介在物やブロホールなど の減少に有利である。

$2 \cdot 1$ 実殹方法

$$
\text { 3. 実 験 結 果 }
$$

i ）溶 解 炉: $750 \mathrm{~kg}$ 塩基性高周波炉 2 基

ii）化学成分: $\mathrm{C} 0 \cdot 29, \mathrm{Si} 0 \cdot 30, \mathrm{Mn} 0.53$, $\mathrm{P} 0 \cdot 16$, S $0 \cdot 016$, Ni $0 \cdot 11$ Cr 0.09 , Mo 0.02

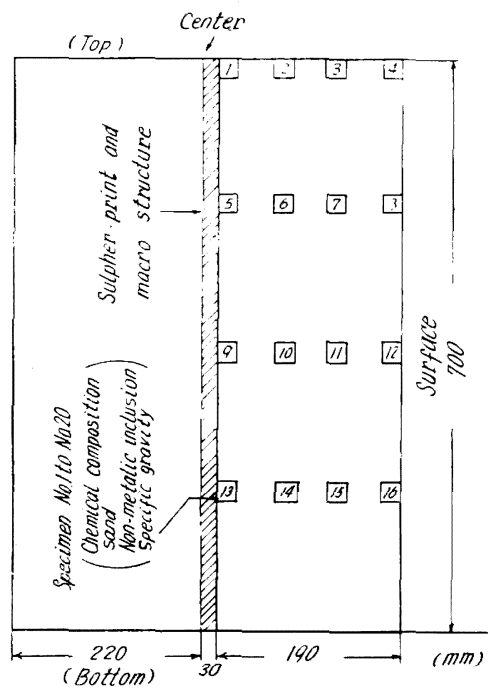

Fig. 1. Test pieces for each test of chemical composition, sand and non-metalic inclusion.

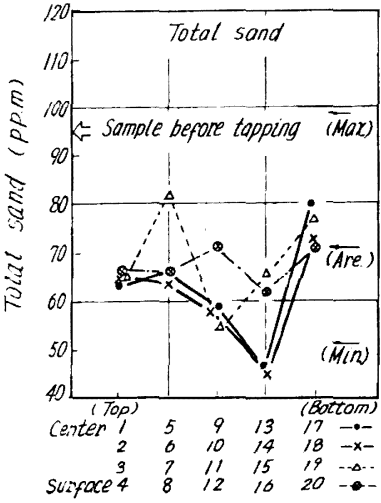

(Specimen number)

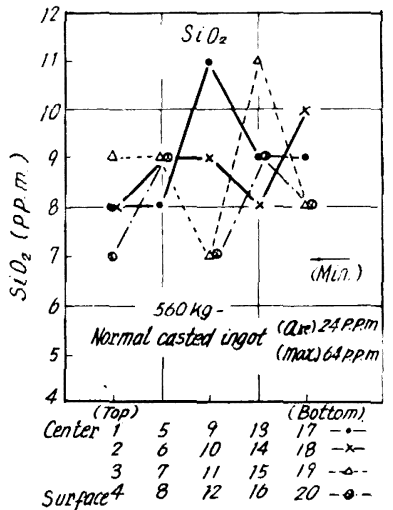

(Specimen number) iii）加圧用金型：密閉金型とした

iv) 加圧条件

使用プレス：2,000 T

缽込温度: $1,540^{\circ} \mathrm{C}$

加圧在门： $1,300 \mathrm{~kg} / \mathrm{cm}^{2}$

金型の予熱温度：常温

加圧時間： $30 \mathrm{~min}$

v) 試験材のサイズ： $420 \mathrm{~mm} \phi \times 680 \mathrm{~mm}^{\mathrm{L}}, 750 \mathrm{~kg}$

$2 \cdot 2$ 実臨結果

$2 \cdot 2 \cdot 1$ サルファープリント扰よびマクロ組織

試験材を縦断し中心面のサルフフーナリントおよびマ クロ組織を観察した。（写真省略）その結果内部は殆ど 偏析がなく普通法のものに此較して著しく良好である。 $2 \cdot 2 \cdot 2$ 化学成分, サンド扰よで非金属介在物

試験材を Fig. 1 のように切断し試料 No.1 No. 20 を採取した。

i ) + ト

温硫酸法によるサンド分析結果を Fig. 2 亿示した。 図中の $\rightarrow$ 印は普通法の $560 \mathrm{~kg}$ 鋼塊のものである.

図より明らであるように，全サンド扔よび $\mathrm{SiO}_{2}$ は普 通法の鋼塊に比較して平均值，バラッキともに小さい. 特に $\mathrm{SiO}_{2}$ の平均值は普通法の鋼塊の $1 / 3$, バラッキは $1 / 14$ で非常に少ない. $\mathrm{Al}_{2} \mathrm{O}_{3}$ は平均值の差は殆どない が，バラッキは加圧試験材の 34〜68 p.p.m. に対して 普通法のものは 30〜86 p.p.m. と大きい.

ii) 化学成分

化学成分のバラッキ（最上值一最下值）を普通法の類 似の大きさの鋼塊のものと比較すると，

バラッキは普通法のものの約 $1 / 2 \sim 1 / 3$ で成分偏析の 少ないことを示している。

iii）顕微鏡的非金属介在物

$\mathrm{A}$ 系介在物の平均值は加圧試験材と普通法の鋼塊とは差

Table 1. Dispersion of chemical analysis.

\begin{tabular}{l|c|c|c|c|c}
\hline & C & Si & Mn & P & S \\
\hline $\begin{array}{l}\text { pressure cast ingot } \\
\text { normal cast ingot }\end{array}$ & 0.03 & 0.01 & 0.01 & 0.002 & 0.003 \\
\hline
\end{tabular}

Fig. 2. Results of sand analysis.

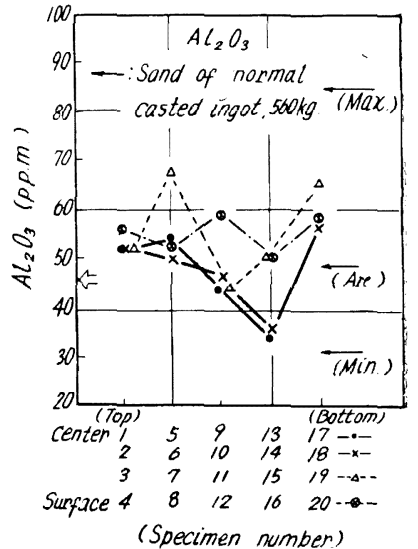


'異はないが，バラッキは普通法の鋼塊の $1 / 2$ である.

C系介在物の平均值は普通法の鋼塊の $1 / 3$, バラッキ は 1/2 である。

非金属介在物の全量と分散はそれぞれ普通法の $1 / 2$ 揖 よび $3 / 4$ で小さい.

すなわち，非金属介在物は溶鋼の加圧によつて 絶対 量，偏析度ともに著しく減少すること荤している。

$2 \cdot 2 \cdot 3 \approx の$ 他

その他加圧試験材は比重が増加し, 内部が均質である ことが推定され，また機械的性質もかなり向上してい る.

\section{4. 結言}

0.3\% C の溶銅に密閉金型内に扣いて $1300 \mathrm{~kg} / \mathrm{cm}^{2}$ の高圧を加えて凝固させ，鐝塊本体重量 $750 \mathrm{~kg}$ の中型 鎆塊をつくり，溶鋼を高圧下で㠜固させたときの鋼塊の 内部性状と鎆䨘がどのように変化するかを調查した。こ の結果を要約すると次のでとくである。

1) Sulpher print でははとんど偏析が認められな ().

また内部欠陌（ブロホール，ザク症，砂疵など）が全 然発生していない.

2)化学成分の偏析度は普通法の鋼塊に比較して 約 1/2〜1/3 である.

3）顕微鏡的非金属介在物は普通法の鎆塊に比較して 少なく, 特にC 系介在物の減少が著しく, 平均値は $1 / 2$, 偏析度は $3 / 4$ である.

4）全サンド量の平均值は普通法の鋼塊の $85 \%$, 偏 析度は $70 \%$ である. 特に $\mathrm{SiO}_{2}$ の減少が著しく，平均 值は $1 / 3$, 偏析度は $1 / 14$ である。

これらの結果は, 加圧することにより, 溶鋼の凝固点
の上昇，扣よび熱卮導率の向上，Air Gap の消失など の現象が生し，てのため，溶鋼の急速な凝固と，さらに は加圧下に打ける溶鋼の粘性增加，成分の拡散速度の減 少, 水素, 酸素などの溶解度の增大の諸現象によつて容 易に理解される。

\section{交献}

1) D. TchernofF: J. Iron \& Steel Inst. (U. K.), 2 (1902), p. 212.

2) H. HARMET:

3）溶鋼の型鍨造：金属 29 巻 2 号 124 .

4) D. N. Bidulza, K. N. Smirnove: Stahl u. Eisen, 81 (1961), p. 1146.

5) A. I. S. I.: Thermochemistry for Steel making (1960).

6) C. Schwarz: Arch. Eisenhüttenw., 32 (1931), p. 139.

7) C. Bendicks, $W$. Ericsson, $U$. G. Ericsson: Arch. Eisenhüttenw., 3 (1930), p. 473.

8) 鉄鋼便覧: 昭和 37 年 4 月発行.

9)石橋正：設計を主とした金属の強さ。

10)美馬源次郎：金属組織学.

11）戸田 盛和：液体籍造論.

12）金属便筧：昭和 35 年 1 月発行.

13）機械工学便覧: 1961 発行.

14) J. Savage: J. Iron \& Steel Inst. (U.K.), 200 (1962), p. 41.

15) A. Dkirshenbaum, J. A. Chahill: Trans. Met. Soc., 224 (1962) 8.

16) J.F. Elliott, M. Gleiser: Thermochemistry for Steel making, 1 (1960). 